\title{
Straw feeding value in sheep and goats: effect of energy and nitrogen supply
}

\author{
JL Tisserand, E Arista, F Faurie \\ INRA-ENSSAA, laboratoire associé de Recherches zootechniques, 26, bd du Dr-Petitjean, \\ 21000 Dijon, France
}

Previous studies have shown that goats utilize nitrogen-deficient diets better than sheep (Tisserand et al, 1991). In order to complete this work, we compared different types of straw complement (maize grain or molasses) given alone or with the addition or urea.

The experiment was conducted on 12 adult castrated rams and 12 adult castrated bucks ( 6 animals from each species equipped with a permanent rumen cannula). Over a 5-wk period, all the animals were successively given ad libitum the following 4 diets: 1) molassed $(20 \%)$ chopped wheat straw $(92.2 \%$ organic matter (OM), $5.4 \%$ crude protein (CP), $37.1 \%$ crude fiber (CF) in DM); 2) chopped wheat straw +190 g grain maize per $\mathrm{kg}$ straw $(93.7 \% \mathrm{OM}, 4.0 \%$ CP, $38.3 \% \mathrm{CF}$ ); 3 ) molassed chopped wheat straw $+6 \%$ urea $(94.4 \%$ OM, $15.6 \% \mathrm{CP}, 35.1 \%$ CF); 4) chopped wheat straw $+6 \%$ urea $+190 \mathrm{~g}$ grain maize per $\mathrm{kg}$ straw $(93.4 \% \mathrm{OM}, 13.6 \%$ $\mathrm{CP}, 34.8 \% \mathrm{CF}$ ). Additional experimental details have been presented in Arista (1991).

Table I shows that goats ingest the 4 diets and more particularly the molassed straw better than sheep. Nevertheless, their OM digestibility measured on d 10 was slightly higher, at least when low nitrogen diets (1 and 2) were fed. The volatile fatty acid (VFA) concentration in rumen fluid was higher in the maize grain-straw diet in both species. Molassed straw feeding resulted in higher VFA levels in goats as compared to sheep, in agreement with the higher quantity of $\mathrm{OM}$ digested.

In conclusion, addition of urea increases rumen ammonia level. Statistical treatment (Arista, 1991) showed that goats, perhaps due to their selection ability, use the nitrogen-deficient molassed straws better than sheep and seem to take better advantage of a urea complement of a corn + straw diet than of a molassed straw diet.

Arista E (1991) Thèse de Doctorat, Université de Bourgogne, $155 \mathrm{p}$

Tisserand $\mathrm{JL}$, Hadjipanayiotou M, Gihad ED (1991) Goat Nutrition (Morand-Fehr, P, ed) Pudoc, Wageningen, 46-60

Table I. Intake, OM digestibility (12 animals) and VFA and NH3-N concentrations (6 animals) in rumen liquid in sheep (S) and goats $(G)$.

\begin{tabular}{|c|c|c|c|c|c|c|c|c|}
\hline & \multicolumn{2}{|c|}{$\begin{array}{c}\text { DM intake } \\
(g / \mathrm{kg} L \text { (w.75) }\end{array}$} & \multicolumn{2}{|c|}{$\begin{array}{l}D O M \\
(\%)\end{array}$} & \multicolumn{2}{|c|}{$\begin{array}{c}\text { VFA } \\
(\mathrm{mmol} / \mathrm{l})\end{array}$} & \multicolumn{2}{|c|}{$\begin{array}{l}\mathrm{NH}_{3}-\mathrm{N} \\
(\mathrm{mg} / \mathrm{l})\end{array}$} \\
\hline & $S$ & $G$ & $s$ & $G$ & $s$ & $G$ & $s$ & $G$ \\
\hline 1) Molassed straw & 24.0 & $33.0^{*}$ & 47.9 & 53.0 & 35.0 & 44.5 & 44.0 & 48.0 \\
\hline 2) Straw + maize & 37.0 & 39.5 & 47.0 & 52.9 & 63.0 & 55.0 & 44.5 & 59.0 \\
\hline 3) Molassed straw + urea & 37.5 & $46.0^{*}$ & 51.5 & 49.0 & 84.0 & 76.5 & 261.5 & 246.5 \\
\hline 4) Straw + urea + maize & 37.6 & $51.5^{*}$ & 59.0 & 56.5 & 93.0 & 90.0 & 259.0 & 261.5 \\
\hline
\end{tabular}

* Significantly higher $(P<0.01)$ than in sheep. 